\title{
STRATEGI PENGEMBANGAN SISTEM JARINGAN TRANSPORTASI DI KOTA MANADO
}

\author{
Ivon M. Mangundap \\ Charles N. Ngangi \\ Caroline B. D. Pakasi
}

\begin{abstract}
ABSRACT
This research was conducted in Manado City, North Sulawesi Province. Data to be used in this research is primary data and secondary data. Primary data were obtained from direct interviews with land transportation users. Secondary data were obtained from various publications issued by the Central Bureau of Statistics Manado City and Regional Agencies related to this research. This research uses SWOT analysis method (Strengths, Weaknesses, Opportunities, Threats), with analysis of development of transportation sub sector using External Internal matrix. The results of this study indicate that the strategy that can be set for the development of transportation network system in Manado City are Development of existing transportation network in Manado City, based on geographical potential and natural resources owned by looking at opportunities from the tourism and transportation sectors potential for the development of sea and coastal transportation, increased discipline of riders, passengers and pedestrians, balancing the percentage of vehicles and minimizing, congestion level with good parking location arrangement, maximize the development of road network in Manado City by optimizing the distribution of goods and human to the transportation of the feeder (transportation between environments) and maximize the integration of modes to access new road network, Improve the quality of human resources for the users Public transport needs to be done so that they are really ready to carry out transportation services to the general public as well as improve the discipline of utilization of driving license to minimize the users of motor vehicles.
\end{abstract}

Keywords: Strategy, Development, Transportation Network System, Manado City

\begin{abstract}
ABSTRAK
Penelitian ini dilaksanakan di Kota Manado Provinsi Sulawesi Utara. Data yang akan digunakan dalam penelitian ini adalah data primer dan data sekunder. Data primer diperoleh dari wawancara langsung dengan masyarakat pengguna transportasi darat. Dan data sekunder Data-data ini diperoleh dari berbagai penerbitan yang dikeluarkan oleh Badan Pusat Statistik Kota Manado dan Perangkat Daerah yang terkait dengan penelitian ini. Penelitian ini menggunakan metode analisis SWOT (Strengths, Weaknesses, Opportunities, Threats), dengan analisis pengembangan sub sector transportasi menggunakan Matriks Internal Eksternal. Hasil penelitian ini menunjukkan bahwa strategi yang dapat di tetapkan untuk pengembangan system jaringan transportasi di kota Manado yaitu Pengembangan jaringan trasportasi yang ada di kota Manado, yang berdasarkan pada potensi letak geografis dan sumber daya alam yang dimiliki dengan melihat peluang dari sektor pariwisata dan trasportasi berpeluang untuk pengembangan transportasi laut dan pesisir, peningkatan disiplin pengendara, penumpang maupun pejalan kaki, menyeimbangkan presentase kendaraan dan meminimalisir tigkat kemacetan dengan pengaturan lokasi parkir yang baik., memaksimalkan pengembangan jaringan jalan di kota Manado dengan mengoptimalkan distribusi barang dan manusia sampai pada angkutan pengumpan (angkutan antar lingkungan) serta memaksimalkan keterpaduan moda untuk mengakses jaringan jalan baru, Peningkatan kualitias sumber daya manusia bagi para pengguna angkutan umum perlu untuk dilakukan sehingga mereka benar benar siap dalam melakukan pelayanan transportasi pada masyarakat umum serta meningkatkan disiplin pemanfaatan Surat Ijin mengemudi untuk meminimalisir pengguna kendaraan bermotor.
\end{abstract}

Kata kunci: Strategi, Pengembangan, Sistem Jaringan Transportasi, Kota Manado 


\section{PENDAHULUAN}

\section{Latar Belakang}

Pembangunan Infrastruktur adalah proses Pembangunan yang penting dalam rangka pencapaian tujuan pembangunan itu sendiri. Salah satu pembangunan infrastruktur adalah pembangunan infrstruktur pada bidang transportasi. Trasnportasi mempunyai fungsi sebagai penggerak, pendorong dan penunjang pembangunan. Transportasi merupakan suatu system yang terdiri dari sarana dan prasarana yang didukung oleh tata laksana dan sumber daya manusia, membentuk jaringan prasarana dan pelayanan serta urat nadi terjadinya proses ekonomi. Hal ini berarti bahwa kelemahan sector transportasi akan menghambat laju pertumbuhan sector lainnya. Permasalahan transportasi selalu terjadi hampir diseluruh kota-kota besar di dunia, dan bahkan sudah dalam keadaan yang sangat kritis. Penyebabnya antara lain: mulai terbatasnya sarana dan prasarana transportasi, urbanisasi yang cepat, tingkat kedisiplinan lalulintas yang rendah, semakin jauh pergerakan manusia setiap harinya, dan mungkin juga system perencanaan transportasi yang kurang baik. Akibatnya kemacetan, tundaan, kecelakaan, gangguan kesehatan, dan permasalahan lingkungan yang tidak dapat dihindari lagi (Tamin, 1997). Kota Manado merupakan kota yang sementara berkembang yang memiliki potensi sumber daya disegala bidang yang menyebabkan munculnya berbagai permasalahan termasuk dibidang transportasi yaitu.

Pengembangan sektor perhubungan diarahkan pada peningkatan pelayanan lalu lintas untuk mobilitas manusia,barang dan jasa baik dalam daerah maupun luar daerah dan bahkan luar negeri, juga untuk meningkatkan laju pertumbuhan perekonomian daerah.Pemerintah Kota Manado menyadari sepenuhnya bahwa perkembangan perekonomian daerah sangat ditentukan oleh ketersediaan infrastruktur arus barang dari dan ke pusat - pusat kegiatan kota. Berbagai langkah dan upaya ditempuh untuk meningkatkan infrastruktur wilayah, terutama untuk memenuhi kebutuhan dan harapan masyarakat. Keberhasilan pengoperasian sistem lalu lintas terdiri ketiga komponen - jalan, manusia dan kendaraan harus kompatibel. Dalam kenyataan sehari-hari di kota Manado hal ini tidak pernah terjadi, akibatnya sistem lalu lintas jalan seringkali gagal. Kecelakaan jalan, kemacetan dan gangguan lalu lintas merupakan contoh kegagalan sistem dan hampir semua kasus diakibatkan oleh ketidak sesuaian antar ketiga komponen, atau antar satu komponen dan lingkungan dimana sistem beroperasi. Dengan melihat perkembangan transportasi Kota Manado maka perlu dilakukan kajian untuk mengidentifikasi permasalahan terkait transportasi dan kebutuhan pengembangannya dengan memperhatikan perencanaan ruang Kota Manado dan berbagai peluang perkembangan perekonomian kota. Transportasi perkotaan mengalami permasalahan sangat serius akibat dari tekanan migrasi desa ke kota dan perkembangan kota itu sendiri, hingga pembiayaan transportasi yang sangat kompleks. Permasalahan transportasi di Kota Manado menjadi salah satu masalah utama yang menuntut perhatian untuk segera ditangani. Kemacetan lalu lintas akibat bertambahnya jumlah kendaraan sementara lebar badan dan panjang jalan tetap, ditambah lagi dengan tidak optimalnya pemanfaatan moda transportasi publik yang mampu memfasilitasi pergerakan penduduk kota selain dengan menggunakan angkutan kota jenis mikrolet yang hanya mampu mengangkut tidak lebih dari 9 penumpang, serta berbagai upaya pemerintah dalam membebaskan Kota Manado dari kemacetan yang pada akhirnya juga menimbulkan titik titik macet baru sehingga permasalahan tidak terselesaikan juga. Pengembangan sektor perhubungan diarahkan pada peningkatan pelayanan lalu lintas untuk mobilitas manusia,barang dan jasa baik dalam daerah maupun luar daerah dan bahkan luar negeri.

\section{Perumusan Masalah}

Seiring dengan berkembangnya masyarakat dan pertumbuhan ekonomi di Kota Manado membuat pertumbuhan sarana transportasi 
terus bertambah, sehingga berpengaruh terhadap tingkat kemacetan lalu lintas di Kota Manado dan menimbulkan biaya sosial (Social cost) yang sangat tinggi. Pengaturan lalu lintas yang tidak tepat ditambah infrastruktur jalan yang tidak memadai serta volume lalu lintas yang melebihi kapasitas jalan menambah parahnya kemacetan, dan banyak lokasi on street parkir illegal dan dijalan arteri/padat lalu lintas. Tidak seimbangnya persentase pertambahan jumlah kendaraan dengan persentase pertambahan prasarana jaringan jalan serta belum adanya alternatif jaringan transportasi seperti lewat laut menyebabkan beban transportasi sepenuhnya berada pada jaringan jalan yang ada. Pembangunan kota Manado memerlukan dukungan system transportasi yang efisien sebagai salah satu prasyarat guna kelangsungan dan terjaminnya pelaksanaan pembangunan . Kota Manado sebagai "waterfront city"di teluk Manado yang memiliki potensi bagi pengembangan trasnportasi air sudah selayaknya menjadi alternatif moda transportasi. Penggunaan petugas lalu lintas dalam jumlah yang besar bukan merupakan solusi yang efisien untuk melakukan pengaturan lalu lintas, sementara untuk melakukan penambahan atau pelebaran jalan membutuhkan anggaran yang besar dan waktu yang lama. Berdasarkan kondisi di atas, maka yang menjadi rumusan masalah adalah : bagaimana strategi pengembangan sistem jaringan transportasi di Kota Manado.

\section{Tujuan Penelitian}

Berdasarkan perumusan masalah di atas, maka yang menjadi tujuan penelitian ini adalah menemukan strategi untuk pengembangan sistem jaringan transportasi di Kota Manado.

\section{Manfaat Penelitian}

1. Secara Teoritis. Dapat memberikan gambaran tentang kondisi dan strategi pengembangan jaringan transportasi guna menanggulangi kemacetan di Kota Manado.
2. Secara Praktis. Dapat menambah ilmu pengetahuan tentang transportasi dalam kaitannya dengan pengembangan jaringan transportasi di Kota Manado.

\section{METODOLOGI PENELITIAN}

\section{Tempat dan Waktu Penelitian}

Penelitian ini dilaksanakan di Kota Manado Provinsi Sulawesi Utara. Waktu Penelitian Penelitian ini direncanakan akan dilakukan dalam jangka waktu 3 bulan dari bulan Maret sampai dengan bulan Juni 2017.

\section{Metode Pengumpulan Data}

Data yang akan digunakan dalam penelitian ini adalah data primer dan data sekunder . Data primer diperoleh dari wawancara langsung dengan masyarakat pengguna transportasi darat. Menurut Sugiyono (2008) dalam penelitian dengan pendekatan kualitatif penentuan besarnya jumlah responden tidak ada ukuran yang mutlak. Responden dipilih dengan tujuan untuk mendeskripsikan suatu gejala social atau masalah social tertentu berdasarkan pada pertimbangan tertentu sehingga disebut sebagai sampling bertujuan (purpose sampling). Sedangkan yang menjadi responden dalam penelitian ini adalah masyarakat yang menggunakan transportasi umum dan transportasi pribadi yang melewati ruas jalan tertentu dan berada pada tingkat kemacetan. Dalam penelitian ini sampel masyarakat sekitar hanya diambil 10 orang karena tidak seluruh masyarakat yang akan dihitung mewakili kriteria untuk menjadi responden dalam penelitian ini. Sedangkan untuk penentuan jumlah 10 orang hal ini dikarenakan responden yang diambil benar benar responden yang hamper setiap hari menggunakan jalur jalan yang macet. Untuk bisa mendapatkan informasi secara mendalam dan dapat dipercaya maka peneliti menggunakan 10 responden sebagai pengguna transportasi darat di ruas jalan yang 
selalu mengalami kemacetan pada saat pagi dan sore hari di kota Manado yang terdiri dari 7 informan $(70 \%)$ perempuan, dan 3 informan $(30 \%)$ laki laki. Data sekunder diperoleh dari instansi yang terkait dengan penelitian yaitu Dinas Perhubungan Kota Manado, Badan Pusat Statistik Kota Manado dan Dinas Pekerjaan Umum Kota Manado.

\section{Jenis Data}

Penelitian ini menggunakan data sekunder dengan periode pengamatan tahun 2016 sampai 2017. Data-data ini diperoleh dari berbagai penerbitan yang dikeluarkan oleh Badan Pusat Statistik Kota Manado dan Perangkat Daerah yang terkait dengan penelitian ini. Data-data ini meliputi :

1. Jumlah penduduk Kota Manado

2. Jumlah jurusan/trayek angkutan kota yang ada di Kota Manado

3. Jumlah angkot (per unit) dan Taxi yang beroperasi

4. Daerah / wilayah yang dilalui angkutan kota

5. Pergerakan jumlah pendududk di Kota Manado dan sekitarnya

6. Jumlah kendaraan bermotor di Kota Manado

7. Daya tampung dan prasarana Terminal 8.

\section{Variabel Penelitian}

Dalam penulisan ini perlu adanya kesamaan pemahaman terhadap variable yang akan diteliti dalam pengertian strategi pengembangan jaringan transportasi di kota Manado, maka perlu adanya definisi operasional variable. Variable yang digunakan dalam analisis ini adalah analisis SWOT terdiri dari Kekuatan (Strengths), Kelemahan (Weaknesses), Peluang (Opportunities) dan Ancaman (Threats) adalah sebagai berikut :

1. Faktor Internal :

1. Kekuatan (Strengths)

1). Transportasi darat merupakan moda transportasi yang paling dominan yang digunakan oleh masyarakat untuk melaksanakan setiap kegiatan dari-menuju suatu tempat untuk beraktivitas.

2). Mempunyai keterpaduan yang erat dengan sistem jaringan transportasi laut dan udara.

3). Sangat menunjang kelancaran distribusi orang dan barang ke seluruh wilayah daratan

4). Pengembangan Jalan Tol ManadoBitung dan Manado-Tomohon yang mendukung mobilitas penduduk.

5). Trasnportasi merupakan sektor vital dari setiap proses pembangunan yang dilakukan dan urat nadi terjadinya proses ekonomi

b. Kelemahan (Weaknesses)

1). Disiplin pengendara, penumpang, maupun pejalan kaki masih kurang.

2). Tidak seimbangnya persentase pertambahan jumlah kendaraan dengan persentase pertambahan prasarana jaringan jalan

3). Jumlah angkutan umum dalam kota dan luar kota yang tinggi

4). Kemacetan menimbulkan biaya social (social cost) yang sangat tinggi.

5). Banyak lokasi on-street parking illegal dan di jalan arteri/padat lalu lintas

6). Kurang terjaminnya kebutuhan akan rasa aman, kebutuhan akan tepat waktu, kebutuhan akan lama perjalanan yang diderita dalam pelayanan angkutan umum serta cara mengemudikan kendaraan yang sembarangan dan membahayakan keselamatan

2. Faktor Eksternal :

a. Peluang (Opportunities)

1). Otonomi Daerah :

2).Berkembangnya pembangunan di Kota Mando seiring dengan berkembangnya kepariwisataan.

3). Letak Geofrafis Kota Manado yang strategis

4). Pembangunan jaringan transportasi jalan yang baru.

5). Sumber daya alam di Kota Manado sangat berpotensi untuk pengembangan sector pariwisata dan transportasi 


\section{b. Ancaman (Threats)}

1). Banyaknya pelanggaran dan kecelakaan lalu lintas

2). Semakin mudahnya proses pemilikan kendaraan pribadi baik mobil maupun sepeda motor.

3). Tekanan Migrasi desa ke kota dan perkembangan kota Manado sendiri.

4). Meningkatnya harga tanah di pusat kota

5). Dibukanya pusat perbelanjaan yang baru menambah kemacetan diruas jalan tertentu

\section{Analisis Data}

Penelitian kualitatif tidak memiliki rumus atau atauran absolute untuk mengolah dan menganalisis data (Poerwandari, 2007) tujuan akhir analisis data kualitatif adalah mempeoleh makna, menghasilkan pengertian pengertian konsep konsep serta mengembangkan hipotesis atau teori baru. Analisis data kualitatif adalah proses mencari serta menyusun secara sistematis data yang dipeoleh dari hasil wawancara, catatan lapangan, dan bahan bahan lainnya sehingga mudah dipahami agar dapat diinformasika kepada orang lain (Bogdan 1994). Analissi data penelitian kualitatif dilakukan dengan mengorganisasikan data, menjabarkannnya kedalam unit unit, melakukan sintesa menyusun kedalam pola memilih mana yang penting dan mana yang akan dikaji sehingga dapat dibuat suatu kesimpulan untuk disampaikan kepada orang lain. Miles Huberman 1984 mengemukakan bahwa aktifitas dalam analisis data kualitatif dilakukan secara interaktif berlangsung secara terus menerus sampai tuntas, sehingga datanya jenuh. Ukuran kejenuhan data ditandai dengan tidak diperolehnya lagi data atau informasi baru. Aktifitas dala analisis meliputi reduksi data, penyajian data, serta penarikan kesimpulan dan verifikasi. Dalam penelitian ini data yang akan peneliti kumpulkan akan dianalisis secara kualitatif dan deskripsi sesuai hasil wawancara melalui tahapan sebagai berikut : Data primer yaitu data yang diambil secara langsung melalui survey pada lokasi yang bersangkutan secara langsung melalui kuesioner. Kuesioner ini diajukan pada responden. Responden disini adalah sampel dari populasi penumpang berangkat kerja maupun pulang kerja yang mengalami kemacetan yang monoton diruas jalan yang sama. Selanjutnya dilakukan dengan analisis SWOT (Strengths, Weaknesses, Opportunities, Threats). Mengidentifikasi factor internal dan factor eksternal yang disusun dalam matriks IFAS (Internal Faktor Analysis System) dan matriks EFAS (External Factor Analysis System), Kemudian dianalisis dengan SWOT sehingga menggambarkan secara jelas kekuatan dengan memanfaatkan peluang, kekuatan untuk menghilangkan ancaman, mengurangi kelemahan untuk memperoleh peluang dan cara mengatasi kelemahan untuk menghilangkan ancaman.

\section{Model Analisis Data}

Dalam Penelitian ini, model yang digunakan oleh penulis yaitu, analisis SWOT. Dalam analisis SWOT ditentukan nilai pada bobot dan skor berdasarkan pada hasil analisis data yang diperoleh dari responden. Bobot yang ditentukan berdasarkan penting atau tidak pentingnya suatu variabel yang dapat dilihat dalam pengembangan pada sub sektor transportasi di Kota Manado, yang mana menyangkut factor internal dan factor eksternal

Tabel 1. Rumus Pembobotan

\begin{tabular}{cccc}
\hline & Kekuatan dan Peluang & Bobot & $\begin{array}{c}\text { Kelemahan } \\
\text { dan } \\
\text { Ancaman }\end{array}$ \\
\hline Kategori & Sangat penting & 1,00 & Sangat \\
& Penting & 0,75 & penting \\
Standart & 0,50 & Penting \\
& Tidak penting & 0,25 & Standart \\
& Sangattidak penting & 0,10 & Tidak \\
& & & penting \\
& & & Sangat \\
tidak \\
\end{tabular}


a. Rating yang diberikan berdasarkan pada baik atau tidaknya suatu variabel dalam mempengaruhi variabel lain dalam pengembangan pada subsector transportasi di Koita Manado.

Tabel 2. Rumus Peratingan

\begin{tabular}{|c|c|c|c|}
\hline & $\begin{array}{l}\text { Kekuatandan } \\
\text { Peluang }\end{array}$ & Bobot & $\begin{array}{c}\text { Kelemahan } \\
\text { dan } \\
\text { Ancaman }\end{array}$ \\
\hline \multirow[t]{5}{*}{ Kategori } & Sangat baik & 4 & Sangat baik \\
\hline & Di atas rata- & 3 & Di atas rata- \\
\hline & rata & 2 & rata \\
\hline & Rata-rata & 1 & Rata-rata \\
\hline & $\begin{array}{c}\text { Dibawah rata- } \\
\text { rata }\end{array}$ & & $\begin{array}{l}\text { Dibawah } \\
\text { rata-rata }\end{array}$ \\
\hline
\end{tabular}

\section{HASIL DAN PEMBAHASAN}

\section{Deskripsi Wilayah}

\section{Luas dan Batas Wilayah Kota Manado}

Kota Manado merupakan Ibukota dari Provinsi Sulawesi Utara yang terletak di teluk Manado, dan dikelilingi oleh daerah pegunungan. Secara geografis, Kota Manado terletak di antara $: 1^{\circ} 30^{\prime}-1^{\circ} 40^{\prime}$ Lintang utara ,124 $44^{\circ}-126^{\circ} 50^{\prime}$ Bujur Timur. Kota Manado berbatasan, Sebelah Utara dengan : Kec. Wori (Kab. Minahasa Utara) dan Teluk Manado, Sebelah Timur dengan : Kec. Dimembe (Kab. Minahasa Utara) dan Kec. Pineleng (Kab, Minahasa), Sebelah Selatan dengan : Kec. Pineleng (Kab. Minahasa), Sebelah Barat dengan: Teluk Manado /Laut Sulawesi. Kota Manado sebagai ibukota Provinsi Sulawesi Utara yang terletak pada bagian utara jazirah pulau Sulawesi, dan memiliki jarak dengan beberapa kota dan kabupaten lainnya di Sulawesi Utara yaitu sebagai berikut :

- Manado - Airmadidi

- Manado - Bitung

- Manado - Tomohon

- Manado - Tondano

- Manado - Amurang

- Manado - Ratahan

15,00 kilometer

44,30 kilometer

21,60 kilometer

35,05 kilometer

65,08 kilometer

67,07 kilometer

- Manado - Kotamobagu 183,72 kilometer

- Manado - Molibagu 242,06 kilometer

Secara administratif Kota Manado terbagi atas sebelas kecamatan dan delapan puluh tujuh kelurahan.Sesuai dengan Peraturan Pemerintah Nomor 22 Tahun 1988 luas Kota Manado adalah $18.712,60 \mathrm{Ha}$
Tabel 3. Luas Wilayah Kota Manado Per Kecamatan

\begin{tabular}{cll}
\hline No. & \multicolumn{1}{c}{ Kecamatan } & Luas $(\mathrm{Ha})$ \\
\hline 1. & Malalayang & $3.023,7$ \\
2. & Sario & 183,7 \\
3. & Wanea & $1.318,2$ \\
4. & Wenang & 293,0 \\
5. & Tikala & $1.836,6$ \\
6. & Mapanget & $6,168,3$ \\
7. & Singkil & 386,4 \\
8. & Tuminting & 403,5 \\
9. & Bunaken & $5.099,2$ \\
10 & Bunaken Kepulauan & 0,48 \\
11 & Paal Dua & 8,02 \\
\hline Total & & $18.712,60$ \\
\hline
\end{tabular}

Sumber : Kota Manado Dalam Angka Tahun 2015

Dengan adanya reklamasi pantai Teluk Manado yang dimulai tahun 1995, maka luas daratan Kota Manado telah bertambah \pm 67 ha`Pemerintahan` Kota Manado memiliki sejumlah instansi yang terdiri dari Dinas, Badan dan kantor yang melaksanakan fungsi administrasi dan pengelolaan kota. Dalam konteks pelaksanaan otonomi daerah sekaligus peningkatkan pelayanan kepada masyarakat, Pemerintah Kota Manado melalui Peraturan Daerah Nomor 4 dan 5 Tahun 2000 telah melakukan perubahan status Desa menjadi Kelurahan sehingga jumlah kelurahan bertambah dari 68 menjadi 87 kelurahan.

\section{Kependudukan}

Kesejahteraan penduduk merupakan sasaran utama dari pembangunan. Pembangunan yang dilaksanakan adalah dalam rangka membentuk manusia Indonesia seutuhnya dari seluruh masyarakat Indonesia. Untuk itu pemerintah telah melaksanakan berbagai usaha dalam rangka memecahkan masalah kependudukan. Salah satu usaha untuk menekan laju pertumbuhan penduduk telah dilakukan pemerintah melalui program Keluarga Berencana yang dimulai awal tahun 1970-an .Jumlah penduduk tahun 2015 berdasarkan data BPS berjumlah 534.125 jiwa. Besarnya jumlah penduduk di Kota Manado menyebabkan kepadatan penduduk menjadi cukup tinggi. Dengan luas wilayah 18.712,60 $\mathrm{km}^{2}$. Pemerintahan Kota Manado memiliki sejumlah instansi yang terdiri dari Dinas, Badan dan kantor yang melaksanakan fungsi administrasi dan pengelolaan kota. Dalam konteks 
pelaksanaan otonomi daerah sekaligus peningkatkan pelayanan kepada masyarakat, Pemerintah Kota Manado melalui Peraturan Daerah Nomor 4 dan 5 Tahun 2000 telah melakukan perubahan status Desa menjadi Kelurahan sehingga jumlah kelurahan bertambah dari 68 menjadi 87 kelurahan.

Tabel 4. Jumlah Penduduk Kota Manado Per Kecamatan

\begin{tabular}{|c|c|c|c|}
\hline \multirow{2}{*}{ Kecamatan } & \multicolumn{2}{|c|}{ Jumlah Penduduk } & \multirow{2}{*}{ Jumlah } \\
\hline & Laki-Laki & Perempuan & \\
\hline Malalayang & 27.316 & 26.735 & 56.051 \\
\hline Sario & 9.759 & 10.735 & 23.494 \\
\hline Wanea & 33.756 & 32.780 & 69.536 \\
\hline Wenang & 19.715 & 22.841 & 44.556 \\
\hline Tikala & 37.652 & 33.748 & 72.400 \\
\hline Mapanget & 23.486 & 25.231 & 59.817 \\
\hline Singkil & 31.007 & 27.889 & 61.896 \\
\hline Tuminting & 23.788 & 26.328 & 53.215 \\
\hline Bunaken & 9.946 & 12.133 & 25.079 \\
\hline $\begin{array}{l}\text { Bunaken } \\
\text { Kepulauan }\end{array}$ & 3.677 & 3.447 & 15.124 \\
\hline Paal Dua & 25.448 & 24.509 & 52.957 \\
\hline $\begin{array}{l}\text { JUMLAH/ } \\
\text { Total }\end{array}$ & 216.425 & 218.420 & 534.125 \\
\hline
\end{tabular}

Kota Manado memiliki 3 (tiga) pulau yang termasuk dalam wilayah administrasinya, ketiganya termasuk bagian dari wilayah Kecamatan Bunaken.

Tabel 5. Pulau Yang Ada Di Wilayah Kota Manado

\begin{tabular}{|c|c|c|c|}
\hline $\begin{array}{l}\text { Nama } \\
\text { Pulau }\end{array}$ & Luas & $\begin{array}{c}\text { Panjang } \\
\text { Garis } \\
\text { Pantai }\end{array}$ & $\begin{array}{c}\text { Wilayah } \\
\text { Kelurahan/ } \\
\text { Kecamatan }\end{array}$ \\
\hline$(1)$ & & $(2)$ & $(3)$ \\
\hline $\begin{array}{c}\text { Manado } \\
\text { Tua }\end{array}$ & $\begin{array}{c}1.056,0 \\
2\end{array}$ & 12.280 & $\begin{array}{l}\text { Manado Tua } \\
\text { Satu dan } \\
\text { Manado Tua } \\
\text { Dua Kec. } \\
\text { Bunaken }\end{array}$ \\
\hline Bunaken & 811,21 & 17.570 & $\begin{array}{l}\text { Bunaken dan } \\
\text { Alung Banua } \\
\text { Kec. Bunaken }\end{array}$ \\
\hline Siladen & 27,95 & 2.240 & $\begin{array}{c}\text { Bunaken } \\
\text { Kec.Bunaken }\end{array}$ \\
\hline
\end{tabular}

Sumber : Kota Manado Dalam Angka Tahun 2015

\section{A. Kondisi Transportasi di Kota Manado}

1. Sarana Kendaraan Angkutan Kota

Pola jaringan trayek angkutan umum sangat menentukan sistem pelayanan angkutan umum dan memberi konstribusi pula terhadap permasalahan transportasi. Pola jaringan trayek angkutan umum yang tidak sesuai dengan kebutuhan pengguna angkutan umum menyebabkan tingginya biaya yang harus dikeluarkan oleh pengguna angkutan umum. Angkutan kota di kota Manado di kelompokkan menjadi 5 Basis dan jumlah unit kendaraan umum dapat dilihat dalam tabel dibawah ini.

Tabel 6. Trayek dan Jumlah Unit Kendaraan Angkutan Kota

\begin{tabular}{lc}
\hline Basis Trayek & Jumlah (Unit) \\
\hline Malalayang-Pst kota \& & 112 Unit / Mikrolet \\
Malalayang-Karombasan & 156 Unit / Mokrolet \\
Karombasan - Pusat Kota & 145 Unit / Mikrolet \\
Paal II - Pusat Kota & 105 Unit / Mikrolet \\
Tuminting - Pusat Kota & 157 Unit / Mikrolet \\
\hline $\begin{array}{c}\text { Total } \\
\text { 2015 }\end{array}$ & 675 Unit / Mikrolet \\
\hline $\begin{array}{l}\text { Sumber : Dinas Perhubungan Kota Manado, tahun } \\
\end{array}$
\end{tabular}

Angkutan umum yang tidak sesuai standar akan memberikan kontribusi terhadap permasalahan transportasi dapat menyebabkan penumpang beralih ke model angkutan yang lebih murah, seperti sepeda motor (ojek). Pola jaringan trayek dapat pula menyebabkan tumpang tindih trayek, dan menyebabkan kemacetan. Beberapa pola jaringan trayek dapat disebutkan disini yaitu :

a. radial criss-cross;

b. trunk line with feeders;

c. grid;

d. radial

Pola jaringan trayek angkutan umum akan menentukan letak terminal yang seharusnya di lewati. Letak terminal sebagai titik ikat trayek-trayek harus dipertimbangkan secara matang. Saat ini tercatat ada 4 terminal di Kota Manado dan masing-masing terletak di 
daerah/ kawasan kota yang tersebar di empat kawasan yang berbeda. Keempat terminal tersebut adalah Terminal Malalayang, Terminal Karombasan, Terminal Paal 2 dan Terminal Tuminting. Sebagian besar trayek ini memiliki titik awal/akhir di pusat kota (22 trayek dari 25 trayek), sehingga dapat dimengerti bila pusat kota dipadati oleh kendaraan angkutan umum dan sangat mempengaruhi kelancaran lalu lintas.Secara skematis posisi terminal dan jaringan trayek di Kota Manado dapat dilihat berdasarkan gambar 1. Pola terminal di Kota Manado mengikuti pola central terminating. Dimana posisi pusat kota sebagai titik awal/akhir trayek. Pola terminal dapat digambarkan sebagaimana terlihat pada gambar 1 .

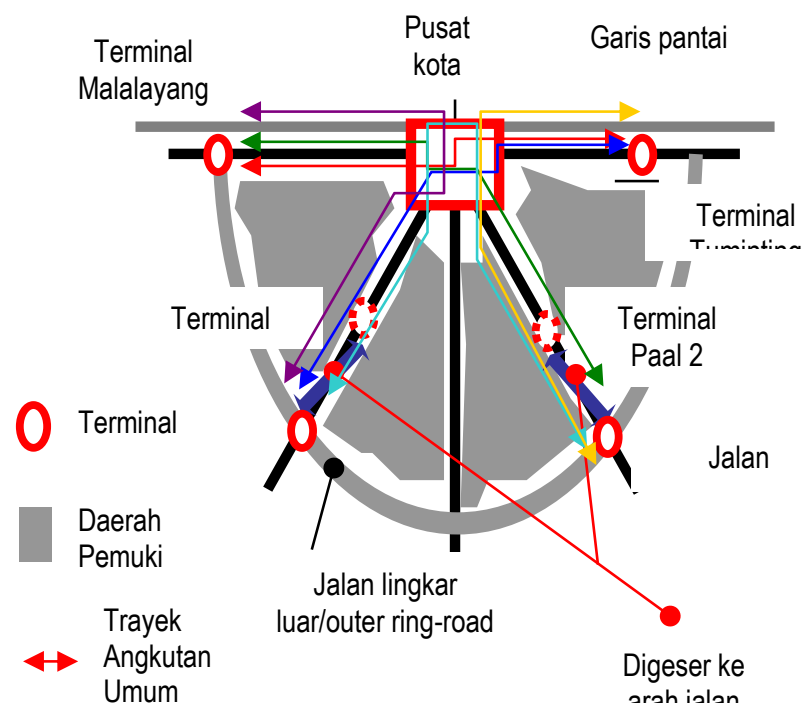

Gambar 1.Posisi Terminal dan Jaringan Trayek di Kota Manado

Sesuai dengan pola ini, maka trayektrayek angkutan kota akan saling menghubungkan diantara ke empat terminal dan masing-masing trayek hanya menyinggung di pusat kota. Dengan pola ini hanya ada 7 trayek yang akan melayani kebutuhan penduduk Kota Manado. Trayek-trayek ini diharapkan seminimal mungkin tumpang tindih dan dapat disebarkan secara merata ke jalan-jalan yang sejajar jalan radial/arteri, sehingga memberi pelayanan daerah hunian sebaik mungkin. Beberapa terminal yang ada di wilayah Kota Manado saat ini dirasakan terlalu dekat dengan pusat kota dan telah memiliki permasalahan yang sangat kompleks untuk dikembangkan lagi, sehingga disarankan untuk direlokasi/digeser ke arah pinggir, hingga ke pertemuan dengan jalan lingkar, selengkapnya sebagai berikut:

- Terminal Paal 2, direlokasi dan dikembangkan disekitar kawasan Liwas dekat dengan kawasan Ring Road.

- Terminal Karombasan, direlokasi dan dikembangkan disekitar kawasan Winangun Atas dekat dengan kawasan Ring Road dengan

- Teminal Tuminting, direlokasi dan dikembangkan di kawasan Molas atau Meras dekat dengan pembangunan jalan Ring Road

- Terminal Malalayang direlokasikan dan dikembangkan di kawasan Malalayang dekat dengan pembangunan Ring Road Winangun Malalayang.

Selain rencana relokasi sejumlah terminal yang ada di wilayah Kota Manado, maka ada juga rencana pembangunan terminal baru dalam rangka mewujudkan sistem sirkulasi dan transportasi yang efektif dan efisien. Angkutan luar kota di kota Manado dilayani oleh beberapa Terminal, adapun terminal yang dimaksud dapat dilihat dalam lampiran 1

\section{B. Status Jalan Berdasarkan Kewenangan}

Jalan Nasional yaitu ruas jalan yang karena tingkat kepentingan dan kewenangan pembinaanya berada pada Pemerintah Pusat. Ruas jalan yang termasuk dalam klasifikasi ini adalah:

1. Jalan Provinsi yaitu ruas jalan yang karena tingkat kepentingannya kewenangan pembinaanya diserahkan kepada Pemerintah Daerah Provinsi. Ruas jalan yang termasuk dalam klasifikasi ini adalah :

- Jalan Kolektor Primer yang menghubungkan ibukota provinsi dengan ibukota kabupaten/kota

- Jalan Kolektor sekunder yang menghubungkan ibukota kabupaten/kota dengan ibukota kabupaten/kota lainnya

- Jalan lainnya yang mempunyai nilai strategis ditinjau dari segi kepentingan Propinsi

2. Jalan Kota/Kabupaten yaitu ruas jalan yang karena tingkat kepentingannya kewenangan pembinaanya diserahkan kepada Pemerintah Daerah Kabupaten/Kota. Ruas jalan yang termasuk dalam klasifikasi ini adalah: 
- Jalan Kolektor Primer yang tidak masuk ke dalam baik jalan nasional maupun jalan propinsi

- Jalan Lokal Primer

- Jalan Sekunder

- Jalan lainnya yang mempunyai nilai strategis ditinjau dari segi kepentingan Kabupaten atau Kota

- Jalan Khusus yaitu jalan yang berdasarkan tingkat kepentingannya bersifat khusus makaa kewenangan pembinaannya diserahkan kepada instansi/badan hukum atau perseorangan yang membangun dan mengelola jalan tersebut.

Dari jumlah panjang jalan di Kota Manado dapat diklasifikasikan nama jalan berdasarkan status yang selengkapnya dapat dilihat pada Lampiran 2. Merujuk kepada Undang-undang No. 38 Tahun 2004 tentang jalan, jalan dapat diklasifikasikan berdasarkan peran dan wewenang pembinaannya. Berdasarkan perannya, jalan dibagi menjadi sistem jaringan primer dan sistem jaringan sekunder, sedangkan berdasarkan kewenangan pembinaannya, jalan dibagi menjadi Jalan Nasional, Jalan Propinsi dan Jalan Kabupaten/Kotamadya dan Jalan Khusus. Berdasarkan kewenangannya panjang jalan yang ada di kota Manado dapat dilihat dalam tabel 7.

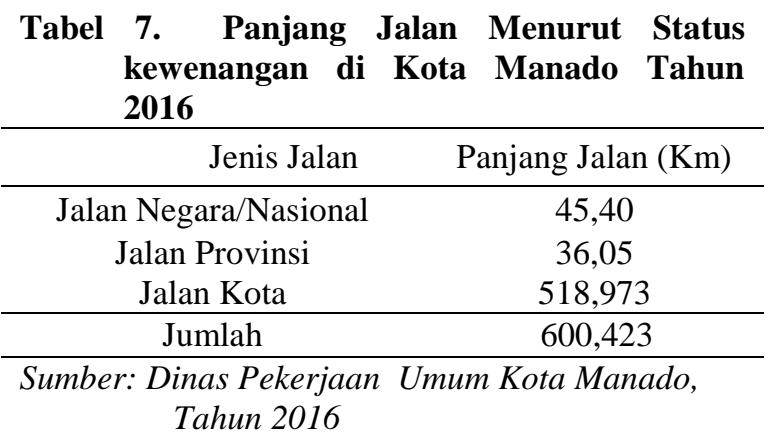

Panjang jalan menurut status kewenangan yang ada di kota Manado dapat dilihat berdasarkan diagram yang ada di bawah ini

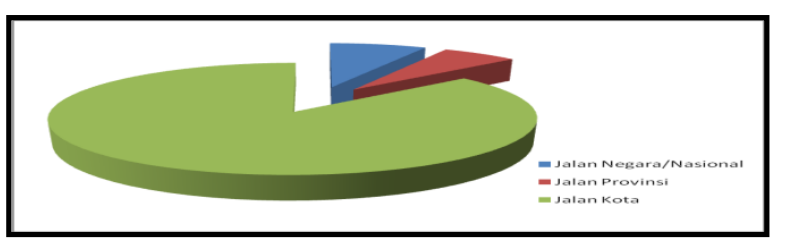

Gambar 2. Diagram Panjang Jalan Menurut Status / Penanganan di Kota Manado

\section{Prasarana Terminal}

Dalam UU.No 22 tahun 2009 tentang Lalulintas dan angkutan jalan ditetapkan bahwa untuk menunjang kelancaran mobilitas orang maupun arus barang dan untuk terlaksananya keterpaduan intra dan antar moda secara lancar dan tertib, di tempat-tempat tertentu dapat dibangun dan diselenggarakan terminal. Pada penjelasan dari pasal tersebut ditegaskan bahwa pada hakekatnya terminal merupakan simpul dan jaringan transportasi jalan yang berfungsi pokok sebagai pelayanan umum antara lain berupa tempat untuk naik turun penumpang dan / atau barang, untuk pengendalian lalulintas dan angkutan kendaraan umum, serta sebagai tempat perpindahan intra dan antar moda transportasi. Dengan mengacu kepada ketentuan normatif yang harus dipenuhi suatu terminal penumpang angkutan jalan sebagaimana tercantum dalam undang-undang tersebut, maka apabila diamati kondisi terminal yang ada di Sulawesi Utara saat ini, dapat dikatakan bahwa kondisi terminal yang ada sudah tidak sesuai lagi dengan kebutuhan masyarakat pengguna jasa dan banyak fungsifungsi pelayanan umum yang jauh dari kualitas yang diharapkan.

Terminal penumpang di Manado, baik yang di Malalayang, Karombasan dan Pal dua dan Tuminting sudah tidak memadai terutama dari ketersediaan ruang tunggu untuk penumpang. Fungsi pokok terminal sebagai tempat perpindahan antar moda transportasi juga belum terpenuhi dengan sebaik-baiknya. berdasarkan data yang diperoleh di Dinas Pekerjaan Umum yang ada di Kota tahun 2016, Kota Manado terdapat 4 (empat) terminal, yaitu :

1) Terminal Malalayang. Type A, luas : 15.000 M2 memiliki daya tampung 470 Armada dengan jumlah kendaraan masuk/keluar ratarata per hari : 460 Kendaraan dan penumpang Turun/Naik rata-rata per hari : 4.782 Orang, jumlah trayek : 2 (AKAP); 19 (AKDP); dan 8 (Angkot).

2) Terminal Karombasan, Type B dengan luas : 8.974 M2 memiliki daya Tampung : 283 Armada dengan jumlah kendaraan masuk/keluar rata-rata per hari : 562 Kendaraan dan jumlah penumpang turun/naik rata-rata per hari : 5.731 Orang, Jumlah Trayek : 16 (AKDP); dan 13 (Angkot). 
3) Terminal Paal Dua, Type B dengan Luas : 6.358 M2, daya Tampung : 224 Armada, kendaraan masuk/keluar rata-rata per hari : 452 Kendaraan, Penumpang Turun/Naik rata-rata per hari : 5.004 Orang, jumlah Trayek : 10 (AKDP); dan 9 (Angkot).

4) Terminal Tuminting, Type $B$ dengan Luas : 250 M2, daya tampung : 35 Armada, kendaraan masuk/keluar rata-rata per hari : 21

Kendaraan, Penumpang Turun/Naik rata-rata per hari : 272 Orang, Jumlah Trayek : 2 (AKDP); dan 7 (Angkot).

Lokasi terminal dan trayek-trayek angkutan umum yang sudah ada, belum sepenuhnya mendukung dengan baik transportasi antar moda ini. Sebagai contoh pembanding dapat diutarakan sebagai berikut; apabila ada seorang calon penumpang pesawat terbang yang akan berangkat ke Tahuna, maka untuk menuju Bandara Sam Ratulangi yang bersangkutan akan mengalami kerepotan untuk mempergunakan angkutan umum. Maka pilihan yang akan ditempuh adalah memakai taksi yang relatif mahal atau memakai kendaraan pribadi. Dapat dikatakan bahwa kondisi terminal angkutan penumpang umum baik lokasi maupun fasilitas yang tersedia sebagai bagian dari system pelayanan angkutan umum di daerah Sulawesi Utara ini belum mampu untuk memberikan dukungan positif untuk mendorong masyarakat memakai kendaraan angkutan umum bahkan secara tidak langsung justru mendorong pemakaian kendaraan pribadi. Saat ini telah ada jenis angkutan umum massal berupa Bus Trans Kawanua, berdasarkan rute yang ada nampaknya telah menjangkau beberapa simpul penting seperti Bandara Sam Ratulangi, Pelabuhan Manado, Pusat-pusat kegiatan perekonomian, dan sebagainya, tetapi berdasarkan pelaksanaan di lapangan masih banyak calon penumpang yang lebih memilih angkutan jenis mikrolet ketimbang angkutan ini. Adapun salah satu faktor penyebabnya adalah frekuensi keberangkatan dan kedatangan dari Bus Trans Kawanua yang masih dirasa sangat kurang. Ketika tingkat pelayanan angkutan umum (baik angkutan kota maupun Bus Trans Kawanua) yang diberikan pada konsumen rendah, maka masyarakat akan mencari alternatif lain sesuai kebutuhan dan kemampuannya, ditambah lagi begitu mudah akses untuk memiliki kendaraan pribadi yang ditawarkan melalui kredit. Akibatnya pertumbuhan jumlah kendaraan pribadi dalam bentuk sepeda motor atau kendaraan roda empat yaitu kendaraan keluarga (station wagon) akan meningkat dengan pesat

4. Jaringan Transportasi Jalan

Perkembangannya transportasi jalan yang ada di Kota Manado sangat dibatasi oleh kondisi kepadatan bangunan dan kepadatan penduduk pada bagian selatan dan tengah kota. Daerah yang padat penduduk dan bangunan menghalangi perkembangan kota ke arah wilayah ini. Kondisi lingkungan ini menjadi salah satu sebab sehingga kegiatan kota sangat terkonsentrasi di pusat kota dan menimbulkan permasalahan transportasi. Berdasarkan pengamatan, kemacetan terjadi di pusat kota disebabkan oleh pertemuan arus yang merupakan dampak dari pola jalan radial yang menuju ke pusat kota, seperti:

- Jl. Piere Tendean

- Jl. Sam Ratulangi

- Jl. R.W Monginsidi

- Jl. Martadinata

- J1. Hasanudin

Berdasarkan data yang diperoleh dari Dinas Perhubungan Kota Manado tahun 2015, Pertumbuhan kendaraan bermotor yang mencapai $12,7 \%$ perlu mendapat perhatian, dan harus dikendalikan untuk menghindari dampak buruk yang akan ditimbulkan kemudian. Hal ini akan semakin membebani Kota Manado, mengingat kondisi topografis yang sangat membatasi perkembangan kota secara merata ke arah timur dan selatan. Reklamasi pantai sementara ini dianggap sebagai salah satu solusi untuk mendapat lahan yang murah, dengan aksesibilitas baik dan mudah dibangun, tetapi penataan jaringan jalan pada daerah reklamasi harus mutlak dilakukan yaitu dengan membangun jalan baru pada kawasan reklamasi sebagai pembagi arus jalan Boulevard. Berdasarkan data yang diperoleh dari dinas Pekerjaan Umum Kota Manado tahun 2015 Pembangunan dan pengembangan jaringan jalan di wilayah Kota Manado adalah sebagai berikut:

1. Ring-road yang sedang dibangun saat ini, sesuai dengan konsep pengembangan yang ditawarkan dapat dianggap sebagai jalan outer ring-road.

2. Pengembangan jaringan jalan Outer Ring-road akan dibuat secara menerus dan terintegrasi dengan jaringan jalan yang sudah ada, yaitu ring-road tahap1.

3. Selanjutnya jaringan jalan outer ring-road akan dilanjutkan dengan pembangunan dan pengembangan jalan ring-road tahap 2 yang 
ada di kawasan Mapanget, dan jalan ring-road tahap 3 di kawasan kecamatan Malalayang.

4. Untuk menjamin akses yang

5. lebih baik antar kawasan diantara ruas jalan radial, dikembangkan jalan-jalan kolektor/lokal yang ada hingga membentuk "inner ring-road".

Penetapan jalan eksisting di kota Manado sebagai Inner Ring Road berdasarkan data dari Dinas Perhubungan kota Manado tahun 2015 terbagi atas :

1). Jaringan jalan primer

- Jaringan Jalan Manibang Kecamatan malalayang

- Jaringan jalan Kompleks Pasar Karombasan

- Jaringan jalan Kampung Jawa Kecamatan Wanea

- Jaringan Jalan Taas Kecamatan Tikala

- Jaringan Jalan Paal 4 Kenari Kecamatan Tikala

- Jaringan Jalan Liwas Kecamatan Tikala

- Jaringan Jalan AA. Maramais Kecamatan Mapanget

- Jaringan Jalan Kima Atas Kecamatan Mapanget

- Jaringan Jalan Edi Gagola Pandu Kecamatan Mapanget

- Jaringan Jalan Batu Saiki Kecamatan Bunaken

- Jaringan Jalan Santiago Kecamatan Tuminting

- Jaringan Jalan Hasanuddin Kecamatan SIngkil

- Jaringan Jalan Hasanuddin Kecamatan Wenang

- Jaringan Jalan Sudirman Kecamatan Wenang

- Jaringan Jalan Sam Ratulangi Kecamatan Wenang

- Jaringan Jalan Sam Ratulangi Kecamatan Sario

- Jaringan Jalan Sam Ratulangi Kecamatan Wanea

- Jaringan jalan Batu Kota Kecamatan malalayang

2). Interchange (Simpang tidak Sebidang) dan Under/Over Pass yang ada, sebagai berikut:

- Interchange Ring Road Tahap I dan Tahap III dengan Ruas Jalan Manado - Tomohon di Winangun (Kawasan Citraland)

- Underpass Ring Road Tahap I dan Jalan Koka.

- Underpass Ring Road Tahap I dan Jalan Liwas

- Interchange Maumbi antara Ring Road Tahap I dan II dengan Ruas Jalan Manado - Bitung

- Overpass antara Ring Road Tahap II dengan Ruas Jalan AA. Maramis.
3). Pengembangan Jalan Tol

Pengembangan Jalan Tol di wilayah Kota

Manado dilakukan dengan memperhatikan beberapa rencana pengembangan jalan tol yang sudah ada, yaitu:

1. Rencana Pengembangan Jalan Tol Manado Bitung;

2. Rencana Pengembangan Jalan Tol Manado Tomohon;

Pembangunan dan pengembangan jalan tol wilayah Kota Manado berupa pengembangan dengan konsep jalan tol layang di atas ruas jalan, yaitu:

a) Pintu tol dalam kota berada di lokasi kawasan belakang Pameran Kayuwatu, Integrated dengan pintu tol Manado - Bitung dan Akses ke Ring Road Tahap I dan Tahap II

b) Jalan tol dalam kota Manado yaitu berupa jalan layang di atas jalan AA Maramis, jalan Martadinata dan jalan Sudirman

c) Pintu Tol di dalam kota di Kawasan Marina Plaza.

d) Pintu tol Manado Tomohon berada di Kawasan Winangun yang berhubungan dengan Interchange Ring Road Tahap I dan Tahap III dengan Ruas Jalan Manado - Tomohon di Winangun

5. Frekuensi Perjalanan

Kota Manado merupakan ibukota provinsi Sulawesi Utara yang terbagi dalam 11 wilayah kecamatan. Adanya 11 wilayah kecamatan ini secara langsung berpengaruh terhadap pola pergerakan masyarakat di Kota Manado. Hal ini mengakibatkan pemilihan moda transportasi menjadi hal yang terpenting untuk mendukung pergerakan masyarakat dalam melakukan berbagai macam aktivitas sehari-hari. Angkutan umum menjadi alternative utama masyarakat dalam melakukan perjalanan, karena tidak dapat dipungkiri bahwa moda angkutan umum menggunakan ruang jalan jauh lebih efisien daripada moda angkutan pribadi.

Faktor penyebab perjalanan menghasilkan pergerakan-pergerakan angkutan di seluruh wilayah termasuk kendaraan pribadi dan umum, motor dan kendaraan barang. Kebutuhan kendaraan atas tipe pergerakan mempunyai variasi-variasi penting secara jam per hari, hari per minggu dan pada waktu-waktu khusus seperti liburan, festival/pawai, acara 
seminar internasional, hari sekolah, dan lainnya. Berdasarkan data yang diperoleh dari Dinas Perhubungan Kota Manado tahun 2015 dapat digambarkan data diagram prsentase jumlah orang yang berpergian dalam sehari di Kota Manado

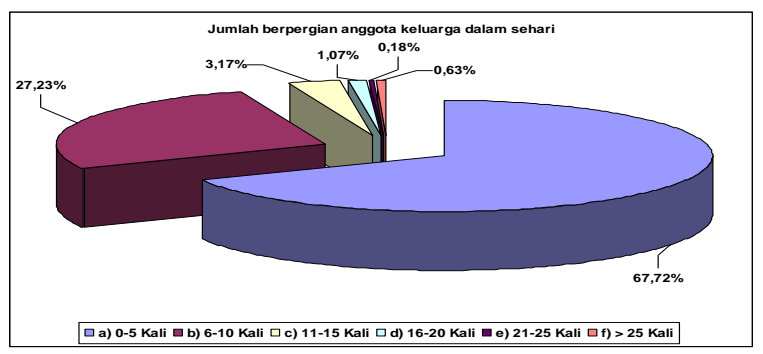

Gambar 3. Diagram Persentase Jumlah Berpergian

(Perjalanan) dalam sehari penduduk di Kota Manado

$$
\text { Kualitas pelayanan angkutan }
$$
penumpang umum yang meliputi keteraturan dan kepastian waktu perjalanan, kapasitas penumpang yang hanya dapat menampung 9 orang, jangkauan trayek, tarif dan kenyamanan yang rendah masih menjadi faktor penentu dalam transportasi. Dengan kondisi kualitas pelayanan angkutan penumpang umum yang rendah maka akan mendorong masyarakat menggunakan kendaraan pribadi misalnya sepeda motor, sehingga pertumbuhan kendaraan bermotor khurusnya sepeda motor di Kota Manado berdasarkan data dari hasil wawancara yang diperoleh dari Dinas Perhubungan yang ada di Kota Mando pada beberapa tahun terakhir menjadi sangat signifikan yaitu jika tahun 2015 telah berjumlah hampir 90.938 unit atau kenaikan $\pm 300 \%$ dari tahun sebelumnya. Begitu juga dengan mobil penumpang tahun 2014 berjumlah 12.908 sedangkan tahun 2015 berjumlah 31.108 kendaraan. Tingkat pertumbuhan kendaraan pribadi tersebut pada akhirnya menimbulkan berbagai permasalahan seperti kemacetan, kesemrawutan, tingkat kecelakaan lalu lintas yang tinggi dan masalah lingkungan. Jenis angkutan umum yang melayani penumpang di kota Manado adalah jenis mikrolet dengan kapasitas 9 (sembilan) tempat duduk. Dengan jumlah kendaraan 715 kendaraan dengan jumlah 39 trayek. Berdasarkan data yang diperoleh, untuk moda angkutan yang digunakan di kota Manado dapat dilihat pada gambar 4 .

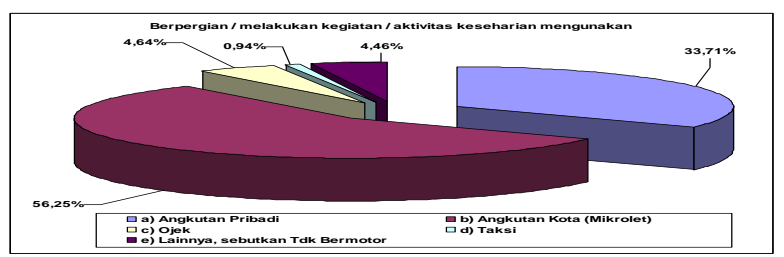

Gambar 4. Diagram Persentase Moda Angkutan

Jumlah penduduk Manado yang menggunakan angkutan pribadi dalam pergerakan kesehariannya adalah sebesar $33,71 \%$, jumlah penduduk manado pengguna angkutan kota/Mikrolet sebesar 56,25 \%, jumlah penduduk manado pengguna angkutan ojek sebesar 4,64\%, jumlah penduduk manado pengguna taksi dalam pergerakan kesehariannya adalah sebesar 0,94\%. 6. Keselamatan Transportasi (Transport Safety)

Di Indonesia, lakalantas diklasifikasikan ke dalam empat kategori dampak yaitu : kecelakaan fatal, luka berat, luka ringan, dan kerusakan kendaraan saja (disebut juga PDO: Property Damage Only). Kecelakaan fatal adalah kategori di mana korban lakalantas meninggal dunia, baik di tempat kejadian perkara maupun akibat luka parahsebelum 30 (tiga puluh) hari sejak terjadinya kecelakaan. Kecelakaan dikatakan berakibat luka parah bilamana korban menderita luka-luka serius dan dirawat di rumah sakit selama lebih dari 30 (tiga puluh) hari. Kecelakaan menyebabkan luka ringan bilamana korban memerlukan perawatan medis atau dirawat di rumah sakit kurangdari 30 (tiga puluh) hari. Sedangkan PDO adalah jenis kecelakaan yang hanya berakibat pada kerusakanbarang hak milik saja. Berdasarkan data dari Kepolisian Resort Kota Manado jumlah kecelakaan yang terjadi meningkat dari tahun 2014 ke tahun 2015 seiring dengan meningkatnya kepemilikan kendaraan di Kota Manado. Total kerugian akibat kecelakaan mencapai Rp. 985.800.000 pada tahun 2015 .

Tabel 10. Jumlah Kecelakaan dan Pelanggaran yang Dilaporkan/ Diselesaikan pada Kepolisisan Resort Tahun 2014-2015

\begin{tabular}{clcc}
\hline No & \multicolumn{1}{c}{ URAIAN } & 2014 & 2015 \\
\hline 1 & Dilaporkan & 69 & 312 \\
2 & Diselesaikan & 67 & 284 \\
3 & Korban & & \\
& - Meninggal & 62 & 61 \\
& Dunia & 24 & 103 \\
& - Luka Berat & 41 & 346 \\
4 & - Luka Ringan & - & 195.800 .000 \\
& Kerugian Materi & & \\
\hline
\end{tabular}

Sumber : Kepolisian Resort Kota Manado (Manado 2015 
Kurangnya kesadaran pengguna jalan akan menyebabkan banyaknya pelanggaran lalu lintas. Data yang berhasil diperoleh dari Kepolisian Resort Kota Manado tahun 2015 sampai dengan tahun 2015 lebih dominan pelanggaran lalu lintas kendaraan yang tidak dilengkapi dengan surat surat dan kendaraan bermotor yang tidak menggunakan helm saat berkendara, yang secara rinci dapat dilihat pada table dibawah ini.

Tabel 11. Jumlah Pelanggaran Lalu Lintas yang Dilaporkan/Diselesaikan pada Kepolisisan Resort Kota Manado Tahun 2014-2015

\begin{tabular}{|c|c|c|c|}
\hline $\mathrm{NO}$ & Jenis Pelanggaran & 2014 & 2015 \\
\hline 1 & Kecepatan & & 1 \\
\hline 2 & Muatan & 241 & 125 \\
\hline 3 & Peruntukan & 1.264 & 909 \\
\hline 4 & Perlengkapan & 4.669 & 5.073 \\
\hline 5 & Helm & 3.642 & 1.183 \\
\hline 6 & Surat-Surat & 7.282 & 4.609 \\
\hline \multirow[t]{2}{*}{7} & Rambu-Rambu & - & 11.316 \\
\hline & Jumlah & 17.098 & 23.216 \\
\hline
\end{tabular}

\section{Analisis SWOT}

Analisis SWOT terdiri dari faktor internal dan eksternal yang secara langsung dan tidak langsung akan mempengaruhi tujuan dari suatu institusi/organisasi. Faktor internal terdiri dari kekuatan (strength) dan kelemahan (weakness), sedangkan faktor eksternal terdiri dari peluang (opportunity) dan ancaman (threat). Keterkaitan antara kondisi internal dan eksternal dapat ditunjukkan dalam empat hubungan, yaitu:

1. memanfaatkan kekuatan untuk meraih peluang,

2. memanfaatkan kekuatan untuk mengantisipasi ancaman,

3. menghilangkan kelemahan untuk meraih peluang,

4. menghilangkan kelemahan untuk

mengantisipasi ancaman.

pada bagian ini akan dijelaskan tentang

kondisi internal dan ekstenal dari wilayah Kota Manado.

1. Faktor Internal

Faktor internal merupakan faktor faktor dari dalam wilayah yang sangat strategis untuk dikembangkan atau dihilangkan berdasarkan pada hasil identifikasi. Factor internal ini terdiri dari kekuatan dan kelemahan yang terdapat di dalam wilayah.

a. Kekuatan (Strengths)

1).Transportasi darat merupakan moda transportasi yang paling dominan yang digunakan oleh masyarakat untuk melaksanakan setiap kegiatan darimenuju suatu tempat untuk beraktivitas.

2). Mempunyai keterpaduan yang erat dengan sistem jaringan transportasi laut dan udara. Aktifitas barang dan manusia keluar-masuk Kota Manado yang meliputi pelabuhan Manado, terminal Karombasan, terminal Paal II, terminal Malalayang dan Bandar Udara Sam Ratulangi, sangat menunjang kelancaran distribusi orang dan barang ke seluruh wilayah dalam kota, provinsi, nasional dan internasional, sehingga secara umum jaringan sarana, prasarana dan pelayanan jasa transportasi Kota Manado telah mampu menunjang kelancaran distribusi orang dan barang ke seluruh wilayah baik lokal, nasional maupun internasional. Partisipasi masyarakat dalam pembangunan prasarana kota. Pembangunan prasarana jalan yang pada mulanya merupakan jalan lingkungan hasil swadaya masyarakat, kemudian ditingkatkan menjadi jalan umum, demikian juga dengan sarana angkutan baik angkutan darat, laut, udara, pos dan telekomunikasi kerjasama antara pihak pemerintah masyarakat dan pihak swasta, hal ini menunjukan bahwa peranan masyarakat dalam pembangunan sarana, prasarana dan usaha bidang perhubungan mempunyai peranan strategis.

3). Jaringan transportasi sangat menunjang kelancaran distribusi orang dan barang ke seluruh wilayah daratan

4). Pengembangan Jalan Tol ManadoTomohon dan Manado-Bitung sangat mendukung mobilitas penduduk. 
5). Jaringan trasnportasi merupakan sektor vital dari setiap proses pembangunan yang dilakukan dan urat nadi terjadinya proses ekonomi

b. Kelemahan (Weakness)

1). Disiplin pengendara, penumpang, maupun pejalan kaki masih kurang.

2). Tidak seimbangnya persentase pertambahan jumlah kendaraan dengan persentase pertambahan prasarana jaringan jalan

3). Jumlah angkutan umum dalam kota dan luar kota yang tinggi

4). Kemacetan menimbulkan biaya social (social cost) yang sangat tinggi.

5). Banyak lokasi on-street parking illegal dan di jalan arteri/padat lalu lintas

6). Kurang terjaminnya kebutuhan akan rasa aman, kebutuhan akan tepat waktu, kebutuhan akan lama perjalanan yang diderita dalam pelayanan angkutan umum serta cara mengemudikan kendaraan yang sembarangan dan membahayakan keselamatan

\section{Faktor Eksternal}

Faktor Eksternal merupakan factor factor yang berasal dari luar wilayah yang berpengaruh terhadap pengembangan wilayah, sehingga perlu untuk diidentifikasi dalam meningkatkan pengembangan tersebut. Factor ekstenal ini terdiri dari peluang dan ancaman yang akan dihadapi dalam pengembangan.

a. Kesempatan (Opportunity)

1) Otonomi Daerah : memberikan kesempatan kepada pemerintah daerah menjalankan otonomi seluas luasnya untuk mengatur dan mengurus sendiri urusan pemerintahan berdasarkan asas otonomi dan tugas pembantuan..

2) Berkembangnya pembangunan di Kota Mando seiring dengan berkembangnya kepariwisataan. Kota Manado yang memiliki potensi lokal keindahan alam seperti taman laut Bunaken merupakan modal dasar berkembangnya kepariwisataan yang sangat khas dengan keramah-tamahan penduduk, sistem sosial dan tata cara kehidupan beragama yang bertoleransi.

3) Letak Geofrafis Kota Manado. Letak Kota Manado sangat strategis sebagai bagian dari Propinsi Sulawesi Utara yang selama ini lebih berperan sebagai daerah transit perdagangan nasional dan internasional dikawasan Pasifik khususnya untuk transportasi, maka pengembangan perhubungan dikota Manado tidak saja untuk memenuhi kebutuhan lokal namun lebih dari itu harus dapat mengantisipasi dan memenuhi kebutuhan transportasi secara umum bagi rencana pembangunan Perhubungan Propinsi Sulawesi Utara.

4) Pembangunan jaringan tranportasi seperti Jalan Ring Road, terminal, tol dan jalur kereta api membawa berbagai dampak. Pada saat pengerjaan proyek otomatis akan banyak menyerap tenaga kerja untuk pekerjaanpekerjaan penggalian, instalasi dan lain-lain, sehingga dapat membuka lapangan pekerjaan baru dan mengurangi angka pengangguran. Bagi sebagian pemilik lahan terutama yang terletak di simpulsimpul jalan akan menikmati naiknya nilai lahan mereka.

5) Sumber daya alam di Kota Manado sangat berpotensi untuk pengembangan sector pariwisata dan transportasi sebagai "Waterfront City" di teluk Manado berpotensi untuk pengembangan kota wisata pantai. Potensi pengembangan wisata dan transportasi air sudah selayaknya menjadi alternative moda transportasi.

b. Ancaman (Threat)

1). anyaknya pelanggaran dan kecelakaan lalu lintas

2). Semakin mudahnya proses pemilikan kendaraan pribadi baik mobil maupun sepeda motor.

3). Jumlah angkutan umum yang ada di kota Manado banyak yang sudah tidak layak digunakan

5). Tekanan migrasi desa ke kota dan perkembangan kota Manado sendiri.

6). Meningkatnya harga tanah di pusat kota mengakibatkan tersebarnya lokasi permukiman jauh dari pusat kota atau bahkan sampai ke luar 
kota yang tidak tercakup oleh jaringan layanan angkutan umum.

7). Dibukanya jalan baru semakin merangsang penggunaan angkutan pribadi karena biasanya di jalan baru belum terdapat jaringan layanan angkutan umum.

8). Dibukanya beberapa mall yang baru menambah kemacetan diruas jalan tertentu

3. Analisis Faktor Internal dan Eksternal

Analisis lingkungan internal dan eksternal sering dikenal pula dengan analisis SWOT ( Strength,Weakness, Opportunity dan Threat). Analisis eksternal dan internal merupakan analisis yang digunakan untuk memahami kondisi internal (Kekuatan dan kelemahan) dan situasi eksternal (peluang dan hambatan)

a. Analisis Faktor Internal

Dalam analisis internal dapat diidentifikasi kekuatan dan kelemahan yang ada diwilayah Kota Manado untuk dapat diperhatikan, sehingga dapat menjadi patokan dalam pengembangan selanjutnya. Dalam analisis factor internal dan eksternal diberi symbol angka. Bobot, skor dan total berdasarkan pada hasil analisis dari factor internal dengan perhitungan hasil kuisioner, seperti yang terlihat pada table 12 .

Tabel 12. Analisif Faktor Internal

\begin{tabular}{cccc}
\hline $\begin{array}{c}\text { Faktor internal } \\
\text { (Kekuatan) }\end{array}$ & Bobot & Rating & $\begin{array}{c}\text { Skor Total } \\
\text { Rata rata }\end{array}$ \\
\hline 1 & 0.103 & 2.2 & 0.226 \\
2 & 0.198 & 2.3 & 0.455 \\
3 & 0.224 & 2.6 & 0.582 \\
4 & 0.206 & 2.4 & 0.494 \\
5 & 0.181 & 2.1 & 0.38 \\
(Kelemahan) & 0.117 & 1.70 & $\mathbf{0 . 1 9 8}$ \\
1. & 0.144 & 2.10 & 0.302 \\
2 & 0.144 & 2.10 & 0.302 \\
3 & 0.131 & 1.90 & 0.248 \\
4 & 0.144 & 2.10 & 0.302 \\
5 & 0.151 & 2.20 & 0.332 \\
& 0.996 & 14.5 & $\mathbf{1 . 8 3 2}$ \\
& Total & & 3.969
\end{tabular}

Berdasarkan Tabel 12 dapat dil2.ihat bahwa angka angka pada bobot dan skor tampak secara jelas factor factor internal yang bersifat sangat strategis dalam menentukan kondisi dan daya saing. Diketahui bahwa jumlah skor untuk keuatan adalah 2.137 dan jumlah skor kelemahan 1.832 nilai skor untuk skor total diperoleh dari hasil penambahan antara skor untuk kekuatan dan skor dari kelemahan sehingga memperoleh nilai 3.969 dengan demikian hasil ini menjadi dasar dalam menganalissi factor internal dengan mengandalkan kekuatan untuk melihat kelemahan kelemahan.

b. Analisis Faktor Eksternal

Dalam analisis ekternal dapat diidentifikasi peluang dan ancaman yang ada di Kota Manado maupun ancaman yang datang dari luar untuk dapat diperhatikan, sehingga dapat menjadi patokan dalam pengembangan selanjutnya. Bobot skor total diberikan berdasarkan pada hasil analisis dari factor eksternal dengan penghitungan hasil kuesioner seperti pada tabel 13 .

Tabel 13. Evaluasi Faktor Eksternal

\begin{tabular}{|c|c|c|c|}
\hline $\begin{array}{c}\text { Faktor Eksternal } \\
\text { Peluang } \\
\text { (Opportunities) }\end{array}$ & Bobot & Rating & $\begin{array}{c}\text { Skor Total } \\
\text { Rata rata }\end{array}$ \\
\hline 1 & 0.22 & 3.70 & 0.814 \\
\hline 2 & 0.173 & 2.80 & 0.484 \\
\hline 3 & 0.181 & 2.90 & 0.524 \\
\hline 4 & 0.186 & 3.00 & 0.576 \\
\hline \multirow[t]{2}{*}{5} & 0.229 & 3.70 & 0.847 \\
\hline & 0.989 & & 3.245 \\
\hline \multicolumn{4}{|l|}{ Ancaman (Threats) } \\
\hline 1 & 0.616 & 2.50 & 0.402 \\
\hline 2 & 0.173 & 2.70 & 0.467 \\
\hline 3 & 0.147 & 2.30 & 0.338 \\
\hline 5 & 0.089 & 1.40 & 0.124 \\
\hline \multirow[t]{3}{*}{6} & 0.089 & 1.80 & 0.207 \\
\hline & 0.685 & & 1.538 \\
\hline & Total & & 4.852 \\
\hline
\end{tabular}


Berdasarkan pada Tabel 13 dapat dilihat bahwa dari angka angka pada bobot dan skor tampak secara jelas factor factor eksternal. Table tersebut diketahui bahwa jumlah skor untuk peluang adalah 3.245 sedangkan jumlah skor pada ancaman adalah 1.538. Nilai skor rata rata diperoleh dari hasil penambahan antara skor untuk peluang dan skor untuk ancaman sehingga memperoleh nilai 4.852 dengan demikian hasil ini dapat menjadi dasar untuk menganalisis factor eksternal dengan melihat peluang dan ancaman yang ada.

B. Matriks Internal Eksternal

Matriks Internal Eksternal merupakan matriks yang dapat mengukur kekuatan internal dan pengaruh eksternal yang akan dihadapi dalam strategi pengembangan jaringan transportasi di Kota Manado . berdasarkan hasil nilai total EFAS adalah 4.852 hasil analisisnya dapat dilihat pada gambar 5. Pada gambar analisis factor internal dan eksternal maka nilai IFAS yang didapat adalah 3.969 sedangkan matriks internal eksternal dapat dilihat bahwa posisi strategi pengembangan system jaringan transportasi di Kota Manado berada pada sel I yaitu Pertumbuhan Strategi

Konsentrasi memalui integrase vertical. Dengan strategi konsentrasi berdasarkan integrase horizontal ini dapat dilihat bahwa kota Manado mempunyai kekuatan yang besar pada strategi pengembangan jaringan transportasi secara horizontal dengan memanfaatkan letak geografis dan potensi sumberdaya alalm (wilayah pesisir) untuk pengembangan jaringan transportasi laut (pesisir).

\begin{tabular}{|c|c|c|c|}
\hline Eksternal & $\begin{array}{c}\text { Kuat } \\
(3.00-4.00)\end{array}$ & $\begin{array}{c}\text { Rata-Rata } \\
(2.00-2.99)\end{array}$ & $\begin{array}{c}\text { Lemah } \\
(1.00-1.99)\end{array}$ \\
\hline $\begin{array}{c}\text { Tinggi } \\
(3.00-4.00)\end{array}$ & $\begin{array}{c}\text { I } \\
\text { Pertumbuhan Strategi } \\
\text { Konsentrasi memalui } \\
\text { integrase vertical }\end{array}$ & $\begin{array}{c}\text { II } \\
\text { Pertumbuhan strategi } \\
\text { konsentrasi berdasarkan } \\
\text { integrasi Horisontal }\end{array}$ & $\begin{array}{c}\text { III } \\
\text { Penciutan } \\
\text { Strategi Turnaround }\end{array}$ \\
\hline $\begin{array}{c}\text { Sedang } \\
(2.00-2.99)\end{array}$ & $\begin{array}{c}\text { IV } \\
\text { Stabilitas } \\
\text { Strategi Stabilitas }\end{array}$ & $\begin{array}{c}\mathbf{V} \\
\text { Pertumbuhan } \\
\text { Stabilitas } \\
\text { Strategi Konsentrasi melalui } \\
\text { integrase horizontal }\end{array}$ & $\begin{array}{c}\text { VI } \\
\text { Penciutan } \\
\text { Startegi divestasi }\end{array}$ \\
\hline $\begin{array}{c}\text { Rendah } \\
(1.00-199)\end{array}$ & $\begin{array}{c}\text { VII } \\
\text { Pertumbuhan } \\
\text { Strategi diversikasi } \\
\text { konsentrik }\end{array}$ & $\begin{array}{c}\text { VIII } \\
\text { Pertumbuhan Strategi } \\
\text { diversikasi konglomerat }\end{array}$ & $\begin{array}{c}\text { IX } \\
\text { Likuiditas } \\
\text { Strategi likuiditas atau } \\
\text { bangkrut }\end{array}$ \\
\hline
\end{tabular}

Gambar 5. Analisis matriks internal eksternal

\section{Analisis Matriks SWOT}

Matriks SWOT merupakan dasar perumusan trategi pengembangan jaringan transportasi di kota Manado. Strategi ini akan dapat diterapkan kebijakan yang diperlukan untuk mendukung pelaksanaan strategi tersebut dalam mendorong proses pengembangan jaringan transportasi, dapat dijelaskan matriks strategi pada gambar 6 matriks SWOT.

a. Strategi Strength - Opportunities (S-O)

Strategi S-O merupakan strategi yang dirumuskan dengan cara memanfaatkan kekuatan yang dimiliki oleh Kota Manado dengan mempergunakan peluang yang ada, seperti moda transportasi yang dominan digunakan, Keterpaduan Sistem Jaringan 
Transportasi Jaringan sarana dan prasaran yang ada dengan melakukan rencana rencana pengembangan jaringan transportasi . seperti yang dikatakan oleh Fahmi (2013), bahwa strategi S-O artinya wilayah menentukann strategi berdasarkan pada kombinasi kekuatan dan peluang yang dapat dimanfaatkan kekuatan untuk menggunakan peluang sebaik baiknya. Kota Manado memilik kekuatan yang sangat kuat, dimana letak geografis yang sangat strategis dan mempunyai wilayah pesisir yang berpotensi untuk pengembangan transportasi moda laut. Hal senada juga disampaikan oleh Fauzi (2006), bahwa moda transportasi yang dominan digunakan dapat dianggap sebagai mesin pertumbuhan (engine of growth) dapat mentransformasi moda transportasi ke dalam " man made capital" yang pada gilirannya akan menghasilkan perkembangan pembangunan yang bebih baik dimasa yang akan dating. Dengan demikian strategi yang diterapkan dengan mengandalkan kekuatan yaitu Peningkatan kunjungan kepariwisataan di kota Manado akan meningkatkan pendapatan penduduk dengan ketersediaan jaringan system transportasi dengan memanfaatkan transportasi moda untuk melaksanakan setiap kegiatan dalam beraktifitas.

b. Strategi Strength-Threats (S-T)

Strategi S-T merupakan strategi yang muncul berdasarkan pada hasil denganmenggunakan kekuatan yang dimiliki oleh Kota Manado untuk mengurangi atau menghilangkan segala macam ancaman dalam pengembangan jaringan transportasi yang diperkirakan akan muncul. Sama halnya yang diungkapkan oleh Fahmi (2013) strategi S- T artinya wilayah harus bisa memanfaatkan kekuatan baik dalam perencanaan dan pemanfaatan sumber daya manusia untuk mengatasi ancaman. Kebijakan pemerintah daerah dalam Pengendalian pengembangan transportasi di wilayah kota Manado perlu dilakukan berdasarkan keterpaduan system jaringan sarana dan prasarana sehingga mampu menunjang kelancaran distribusi barang dan orang ke seluruh wilayah. Kebijakan pemerintah daerah dalam mengatasi ancaman yang semakin menyudutkan peran angkutan umum perlu untuk dilakukan berdasarkan aturan yang berlaku. Seperti halnya yang dikatakan Bustanul dan Didik (2001) dalam hal menanggulangi ancaman yang menyudutkan angkutan umum perlu adanya aturan main dan hokum atau kebijakan. Dengan demikian strategi pengembangan jaringan transportasi yang berkualitas harus berfokus pada sub sector moda transportasi sebagai sector unggulan.

c. Strategi Weakness -Opportunities (WO)

Merupakan strategi yang dihasilkan dengan cara untuk emngurangi kelemahan kelemahan yang ada untuk memperoleh peluang dalam pengembangan jaringan transportasi. Seperti juga yang dikatakan Fahmi (2013) bahwa strategi W-O dilakukan untuk bagaimana meminimalkan kelemahan yang selalu muncul dalam wilayah dengan memanfaatkan peluang yang menguntungkan. Dengan demikian strategi yang dilakukan dalam strategi pengembangan jaringan trasnportasi meningkatakan kualitas sarana dan prasarana transportasi melalui pemanfaatan potensi wilayah yang ada di kota Manado.

d. Weakness - Threats (W-T)

Strategi W-T merupakan startegi yang dihasilkan dengan cara mengatasi kelemahan untuk menghilangkan ancaman. Peningkatan kualitias sumber Daya Manusia bagi para pengguna angkutan massal perlu untuk dilakukan sehingga mereka benar benar siap dalam melakukan pemanfaatan Surat Ijin mengemudi. Seperti juga yang diungkapkan oleh Mulyadi S (2014) dalam bukunya yang berjudul ekonoi sumberdaya manusia yang menjelaskan bahwa peningkatan sumber daya manusia tercermin dalam peningktan kemampuan atau ketrampilan. 


\begin{tabular}{|c|c|c|}
\hline EFAS & $\begin{array}{l}\text { Kekuatan } \\
\text { (Strengths) }\end{array}$ & 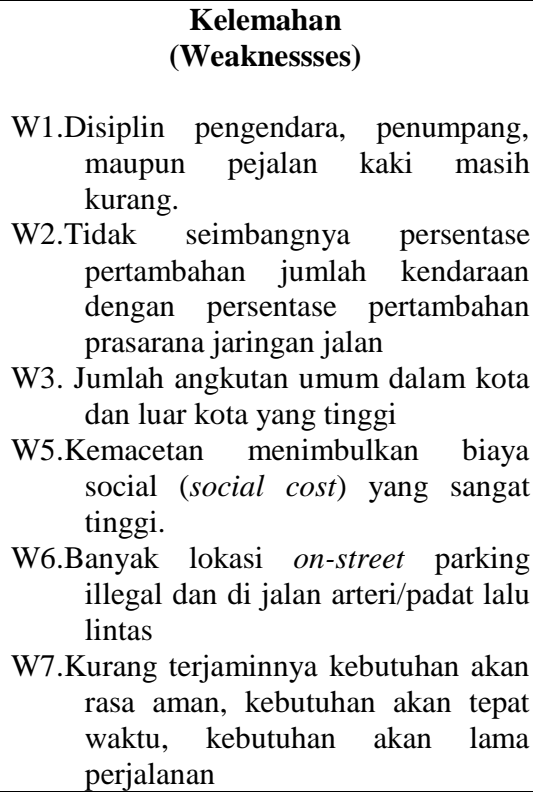 \\
\hline $\begin{array}{l}\text { Peluang } \\
\text { (Opportunities) } \\
\text { O1. Otonomi Daerah } \\
\text { O2.Berkembangnya pembangunan di } \\
\text { Kota Mando seiring dengan } \\
\text { berkembangnya kepariwisataan. } \\
\text { O3.Letak Geofrafis yang strategis } \\
\text { O4.Pembangunan jaringan transportasi. } \\
\text { O5. Sumber daya alam sangat } \\
\text { berpotensi untuk pengembangan } \\
\text { sector pariwisata dan transportasi }\end{array}$ & $\begin{array}{l}\text { Strategi S-O } \\
\text { a. Pengembangan jaringan } \\
\text { trasportasi yang ada di daerah, } \\
\text { yang berdasarkan pada potensi } \\
\text { letak geografis dan SDA yang } \\
\text { ada yang dimiliki daerah } \\
\text { dengan melihat peluang dari } \\
\text { sektor pariwisata dan } \\
\text { trasportasi berpeluang untuk } \\
\text { pengembangan transportasi } \\
\text { sungai }\end{array}$ & $\begin{array}{l}\text { Strategi W-O } \\
\text { a. Peningkatan disiplin pengendara } \\
\text { penumpang maupun pejalan kaki } \\
\text { b. Menyeimbangkan presentase } \\
\text { presentase kendaraan dan } \\
\text { c. Meminimalisir tigkat kemacetan } \\
\text { dengan pengaturan lokasi parkir }\end{array}$ \\
\hline $\begin{array}{l}\text { Ancaman } \\
\text { (Threats) }\end{array}$ & Strategi S-T & Strategi W-T \\
\hline $\begin{array}{l}\text { T1.Banyaknya pelanggaran dan } \\
\text { kecelakaan lalu lintas } \\
\text { 2). Semakin mudahnya proses } \\
\text { pemilikan kendaraan pribadi baik } \\
\text { mobil maupun sepeda motor. } \\
\text { 3) Tekanan Migrasi desa ke kota dan } \\
\text { perkembangan kota Manado } \\
\text { sendiri. } \\
\text { 4). Meningkatnya harga tanah di pusat } \\
\text { kota } \\
\text { 5). Dibukanya pusat perbelanjaan yang } \\
\text { baru }\end{array}$ & $\begin{array}{l}\text { a. Memaksimalkan } \\
\text { Pengembangan jaringan jalan } \\
\text { dengan mengoptimalkan } \\
\text { distribusi barang dan manusia } \\
\text { sampai pada angkutan } \\
\text { pengumpan (angkutan antar } \\
\text { lingkungan) } \\
\text { c. Memaksimalkan keterpaduan } \\
\text { moda untuk mengakses } \\
\text { jaringan jalan baru. }\end{array}$ & $\begin{array}{l}\text { b. Menyediaan sarana dan prasarana } \\
\text { yang baik serta menstabilkan } \\
\text { pasokan BBM, serta meningktakan } \\
\text { disiplin kepemilikan SIM } \\
\text { c. Meningkatkan kebutuhan akan rasa } \\
\text { aman, kebutuhan akan tepat waktu, } \\
\text { kebutuhan akan lama perjalanan } \\
\text { untuk meningktakan jumlah } \\
\text { kunjungan wisatawan dalam } \\
\text { pengembangan sektor pariwisata dan } \\
\text { pelayanan kepada masyarakat } \\
\text { setempat }\end{array}$ \\
\hline
\end{tabular}

Gamba 6.Analisis matriks SWOT 


\section{Pemilihan Strategi}

Penentuan strategi pengembangan jaringan trasnportasi di Kota Manado berdasarkan pada amalisis matriks SWOT dibuat berdasarkan pada hasil analisis dari factor factor strategis baik dari factor internal maupun dari factor eksternal yang terdiri dari kekuatan, kelemahan, peluang dan ancaman. Strategiyang dipilih berdasarkan pada hasil analisis pada matriks SWOT, dirumuskan dalam empat strategi pengembangan jaringan transportasi di Kota Manado yaitu

1. Pengembangan jaringan trasportasi yang ada di kota Manado, yang berdasarkan pada potensi letak geografis dan sumber daya alam yang dimiliki dengan melihat peluang dari sektor pariwisata dan trasportasi berpeluang untuk pengembangan transportasi laut dan pesisir

2. Peningkatan disiplin pengendara penumpang maupun pejalan kaki Menyeimbangkan presentase presentase kendaraan dan Meminimalisir tigkat kemacetan dengan pengaturan lokasi parkir yang baik.

3. Memaksimalkan Pengembangan jaringan jalan di kota Manado dengan mengoptimalkan distribusi barang dan manusia sampai pada angkutan pengumpan (angkutan antar lingkungan) serta memaksimalkan keterpaduan moda untuk mengakses jaringan jalan baru.

4. Peningkatan kualitias sumber daya manusia bagi para pengguna angkutan umum perlu untuk dilakukan sehingga mereka benar benar siap dalam melakukan pelayanan transportasi pada masyarakat umum serta meningkatkan disiplin pemanfaatan Surat Ijin mengemudi untuk meminimalisir pengguna kendaraan bermotor.

\section{KESIMPULAN DAN SARAN}

\section{Kesimpulan}

Dari hasil dan pembahasan yang telah dikemukakan maka dapat di simpulkan bahwa Strategi pengembangan sistem jaringan transportasi di kota Manado terletak pada posisi kuadran I atau terletak antara peluang eksternal dan kekuatan internal. Strategi pengembangan sistem jaringan transportasi di kota Manado dikembangkan secara terpadu dengan moda transportasi laut (pesisir) sesuai dengan potensi letak geografis dan sumber daya alam dengan yang ada di Kota Manado dengan mempertimbangkan keunggulan karakteristik moda, perkembangan teknologi, pemakaian bahan bakar,waktu dan jarak yang ditempuh. Dengan adanya pengembangan jaringan transportasi beberapa masalah kemacetan yang terjadi pada ruas jalan tertentu dari dan menuju pusat kota akan berkurang Strategi pengembangan jaringan transportasi dalam peranannya sebagai unsur penunjang dalam pembangunan diarahkan untuk ditingkatkan kemampuan pelayanan angkutan dan daya dukungnya sesuai dengan kebutuhan masyarakat yang melayani dan menghubungkan pusat kota, pusat kegiatan wilayah serta kawasan-kawasan andalan yang cepat berkembang.

\section{Saran}

Adapun saran-saran yang terkait dengan Strategi pengembangan jaringan transportasi di Kota Manado adalah

Melihat kondisi transportasi yang ada saat ini maka diperlukan keseriusan dan komitmen yang kuat dari pemerintah Kota Manado, masyarakat dan pihak terkait dalam hal perencanaan berhubungan dengan strategi pengembangan jaringan transportasi mulai dari perencanaan umum, pengelolaan dan pengawasan. Perlu dipertimbangkan untuk mengembangkan trasnportasi pesisir dengan memanfaatkan potensi dan letak geografis kota Manado, yang diharapkan dapat menyebarkan pergerakan lalu lintas secara lebih merata ke bagian kota lainnya. Dan peningkatan jalan lingkar diharapkan menghubungkan antar pusat-pusat pertumbuhan baru yang akan dikembangkan di daerah pinggiran kota.

\section{DAFTAR PUSTAKA}

Alhadar. 2011. Analisis Kinerja Jalan Dalam Upaya Mengatasi Kemacetan Lalu Lintas pada Ruas Simpang Bersinyal di Kota Palu. Palu 
Azhar, A 2009. Analisis Dampak Sosial Ekonomi Pengguna Jalan Akibat Kemacetan Lalu Lintas (Studi Kasus Area Universitas Brawijaya Malang) Jurusan Ilmu Ekonomi dan Bisnis Universitas Brawijaya. Malang

Clarkson, O.H, dan Gary R.H., 1988. Teknik Jalan Raya, Edisi keempat Erlangga, Jakarta.

Djajasudarma, T.F, 2006. Metode Linguistik. Refika Aditama. Bandung

Ernie dan Saefullah, 2005. Pengembangan Sumber Daya Manusia. Grasindo. Jakarta

Harahap, S. 2001. Sistem Pengawasan Manajemen, Quantum. Jakarta

Handoko, T.H. 1995. Manajemen Personalia dan Sumber Daya Manusia. BPFE. Yogyakarta

Kamaludin R. 2003. Ekonomi Transportasi: Karakteristik, Teori, dan Kebijakan. Ghalia Indonesia, Jakarta

Miro, F. 2002. Perencanaan Tansportasi, Erlangga. Jakarta

Moleong, L. 2002. Metodologi Penelitian Kualitatif. PT. Remaja Rosdakarya. Bandung

Nasution, 1996. Manajemen Transportasi. Ghalia Indonesia. Jakarta

Nawawi, H. 2003. Manajemen Sumber Daya Manusia Untuk Bisnis Yang Kompetitif. Gadja Mada University Press. Yogyakarta

Poerwandari, E.K. 2007. Pendekatan Kualitatif Untuk Penelitian Perilaku Manusia. LPSP3 Fakultas Psikologi Universitas Indonesia. Jakarta
Prasetyo S. 2016 Kinerja Dinas Perhubungan Kota Bandar Lampung Dalam Pelaksanaan Program ATCS (Area Traffic Control System) di Kota Bandar Lampung ( Studi pada Dinas Perhubungan Kota Bandar Lampung) Fakultas Ilmu Sosial dan Ilmu Politik. Universitas Lampung. Bandar Lampung

Riyanto. 1998. Dasar-Dasar Pembelanjaan Perusahaan. Institut Teknologi Bandung. Bandung

Santoso. I, 1997. Manajemen Lalu Lintas Perkotaan. Institut Teknologi Bandung. Bandung

Sirojuzilam dan Mahali K. 2010. Regional: Pembangunan, Perencanaan dan Ekonomi. USU Pres. Medan

Simbolon. M.M. 2003. Ekonomi Transportasi. Ghalia Indonesia. Jakarta.

Tamin.O.Z. 1997. Perencanaan dan Permodelan Transportasi.Institut Teknologi Bandung. Bandung 